\title{
Retrospective Analysis and Literature Review of Acute Tubulointerstitial Nephritis Cases Linked to Energy Drinks
}

\author{
(iD) Mehtap Çelakıl ${ }^{1}$, (iD) Aysel Taktak² \\ ${ }^{1}$ M.D. Spec., Hatay Training and Research Hospital, Pediatric Nephrology, Hatay, Turkey \\ ${ }^{2}$ M.D. Spec., Mustafa Kemal University Faculty of Medicine, Pediatric Nephrology, Hatay, Turkey \\ Öz
}

\section{Enerji İçeceklerine Bağlı Akut Tubulointerstisyel Nefrit Vakalarının Retrospektif Analizi ve Literatür Taraması}

Amaç: Akut tubulointerstisyel nefrit (aTIN), çocuklarda akut böbrek hasarının nadir bir nedenidir. Enerji içeceklerinin bilinçsiz kullanımına bağlı vakaların görülme sıklığı son yıllarda artmıştır. Bu çalışmada ATN tanısı alan tüm hastalarımız ile birlikte enerji içeceğine bağlı aTıN’ li hastaları detaylı olarak incelemeyi amaçladık.

Yöntem: Bu çalıșmada çocuk nefroloji kliniğinde izlenen akut tubulointerstisyel nefrit (aTıN) hastalarının dosyaları geriye dönük olarak tarandı.

Bulgular: Çalıșmaya 32 hasta dahil edildi (K/E: 22/10). Ortalama yaș $12 \pm$ 4,3 yıl (9-17) idi. Etiyolojide en sık nedenler ilaçlar (18; \% 56,2), enerji içecekleri $(9 ; \%$ 28,1) idi. En sık görülen bașvuru semptomları kusma (\%84,3), yorgunluk (\% 68,7), hipertansiyon (\% 56,2), karın ağrısı $(\% 40,6)$, eklem ağrısı $(\% 34,3)$, ateș $(\% 31,2)$ idi. Etken madde alımı ile semptomların bașlangıcı arasındaki ortalama süre $9 \pm 4,1$ gündü. Sonuç: Enerji içeceği kullanımının son yıllarda aTIN nedenleri arasında yer alması önemli bir sağlık sorunudur. Akut böbrek hasarı ile bașlayan ve $\mathrm{KBH}$ ile sonuçlanan ciddi yan etki profili nedeniyle özellikle genç hastaların anamnezinde mutlaka sorgulanması gereken bir nedendir.

Anahtar Kelimeler: Akut Tubulointerstisyel Nefrit, Enerji İçeceği, Prognoz

\section{Abstract}

Retrospective Analysis and Literature Review of Acute Tubulointerstitial Nephritis Cases Linked to Energy Drinks

Objective: Acute tubulointerstitial nephritis (aTIN) is a rare cause of acute renal injury in children. The incidence of cases linked to insensible use of energy drinks has increased in recent years. In this study, we aimed to examine patients with aTIN connected to energy drink in detail in our own patients.

Methods: In this study, the files of patients with acute tubulointerstitial nephritis (aTIN in the pediatric nephrology clinic were retrospectively screened.

Results: 32 patients were included in the study (F/M: 22/10). Mean age was 12 \pm 4.3 years (9-17). The most common causes in etiology were drugs (18; 56.2\%) and energy drinks (9; 28.1\%). The most common attendance symptoms were vomiting (84.3\%), fatigue (68.7\%), hypertension (56.2\%), abdominal pain (40.6\%), joint pain (34.3\%), fever (31.2\%). The mean duration from onset of symptoms to first attendance at hospital was $3.8 \pm 2.1$ days, with the mean duration between first intake of causative agent to onset of symptoms $9 \pm 4.1$ days.

Conclusion: The inclusion of energy drink use among candidates for causes of aTIN in recent years is an important health problem. Due to serious side effect profile beginning with acute kidney injury and resulting in CKD, it is a cause that should definitely be questioned in the anamnesis of young patients especially.

Keywords: Acute Tubulointerstitial Nephritis, Energy Drinks, Prognosis

Nasıl Atıf Yapmalı / How to Cite: Celakıl M, Taktak A. Retrospective Analysis and Literature Review of Acute Tubulointerstitial Nephritis Cases Linked to Energy Drinks. MKÜ Tıp Dergisi. 2021;12(43):94-99. https://doi.org/10.17944/mkutfd.941866 


\section{INTRODUCTION}

Acute tubulointerstitial nephritis (aTIN) is a rare cause of acute renal injury in the childhood period in the world in general and may display geographical differences in frequency $(1,2)$. In Turkey, it is encountered as a common cause of acute renal injury (3). With similar clinic and treatment to acute tubular necrosis and with differentiation in pathological diagnosis, both diseases are mostly mentioned under the same heading. Diagnosis of these patients attending with acute renal injury is generally placed with clinical findings, and improvement is possible with symptomatic treatment. As a result, it is among rarely encountered causes (1-3\%) in biopsy series $(4,5,6)$. The most common causes are drugs, infections and autoimmune diseases, while the incidence of cases linked to insensible use of energy drinks has increased in recent years (7). Though there are many studies researching the effects of energy drinks on the kidneys, the number of studies with large case series are very few. In this study, we aimed to contribute to the literature by performing retrospective analysis of 32 patients presenting our clinic due to acute renal injury monitored for aTIN after other causes were excluded and presenting data in detail for 9 cases developing aTIN linked to energy drinks.

\section{MATERIALS AND METHODS}

In this study, the files of patients with acute tubulointerstitial nephritis (aTIN) between 2019 September and March 2021 in the pediatric nephrology clinic of Hatay State Hospital were retrospectively screened. Necessary ethic permission was granted by Mustafa Kemal University ethics committee. The study included a total of 32 patients after exclusion of patients with comorbid glomerular disease, nephrotic syndrome, tubulopathy, and vasculitis diagnosis. Patients had symptoms on attendance (fever, abdominal pain, vomiting, blurred vision, arthralgia, skin rash, headache, hypertension), sociodemographic characteristics (age, sex, educational status, history of intermarriage between parents), clinical-laboratory data (eosinophilia, creatinine, electrolytes, full urine test, microalbumin/creatine levels in urine, eGFR levels, renal biopsy results if present, whether steroid treatment was administered or not) and final status recorded. The GFR value was calculated according to the Schwartz formula. Eosinophilia was accepted as above $5 \times 10^{9} / \mathrm{L}$. Protein excretion above $4 \mathrm{mg} / \mathrm{m}^{2} /$ day in 24-hour urine was assessed as proteinuria. For those who could not have urine collected, spot urine protein/creatinine ratio was assessed. Values above $0.5 \mathrm{mg} /$ $\mathrm{mg}$ for those under 2 years and above $0.2 \mathrm{mg} / \mathrm{mg}$ for those older than 2 years was defined as proteinuria and microalbuminuria was defined as 30-300 mg/g. Acute tubulointerstitial nephritis diagnosis was placed clinically. Renal biopsy was performed for 2 patients attending due to acute renal injury with no etiology found. Nine patients with history of energy drink intake with various doses and frequencies within the last 3 months before attendance were assessed in detail. Data for all patients are presented retrospectively.

\section{Table I: Sociodemographic-clinical features of} patients with aTlW diagnosis

\begin{tabular}{|c|c|c|}
\hline Characteristics & Value $(n)$ & $\%$ \\
\hline Age (year \pm SD) & $12 \pm 4.3(9-17)$ & \\
\hline Gender(female/male) & $22 / 10(2.2)$ & \\
\hline Etiology & (n) & $(\%)$ \\
\hline Drugs & 18 & 56.2 \\
\hline Energy drinks & 9 & 28.1 \\
\hline Idiopathic & 3 & 9.3 \\
\hline TINU & 2 & 6.2 \\
\hline Attendance symptoms & (n) & $(\%)$ \\
\hline Vomiting & 27 & 68.7 \\
\hline Fatigue & 22 & 56.2 \\
\hline Hypertension & 18 & 40.6 \\
\hline Abdominal pain & 13 & 34.3 \\
\hline Arthralgia & 11 & 31.2 \\
\hline Fever & 10 & 9.3 \\
\hline Skin rash & 3 & 3.1 \\
\hline Eye pain & 1 & 3.1 \\
\hline Oliguria-Anuria & 1 & 68.7 \\
\hline Eosinophilia (n)(\%) & 2 & 6.2 \\
\hline Proteinuria (n)(\%) & 13 & 40 \\
\hline Microalbuminuria (n)(\%) & 24 & 75 \\
\hline \multicolumn{3}{|c|}{ Urinary ultrasonography } \\
\hline Renal parenchymal disease(n)(\%) & 25 & 78.1 \\
\hline Increase in kidney size $(n)(\%)$ & 19 & 59.3 \\
\hline Need for biopsy (n)(\%) & 3 & 9.3 \\
\hline Need for steroid(n)(\%) & 6 & 18.7 \\
\hline $\operatorname{CKD}(n)(\%)$ & 3 & 9.3 \\
\hline Acute hemodialysis(n)(\%) & 1 & 3.1 \\
\hline
\end{tabular}

TINU:Tubulointerstitiel nephritis and uveit ,CKD:chronic kidney disease

\section{Statistical analysis}

Statistical analysis used the IBM SPSS 20.0 (IBM Corp., Armonk, NY, USA) program. Fit to normal distribution was assessed with the Kolmogorov-Smirnov test. As normal distribution was not present, numeric variables are given as median $\left(25^{\text {th }}-75^{\text {th }}\right.$ percentile). Categoric variables are given as frequency (percentage). Differences between groups were determined 
with the Mann-Whitney $\mathrm{U}$ test as normal distribution was not present. For tests of two-way hypotheses, $p<0.05$ was accepted as sufficient for statistical significance.

\begin{tabular}{|c|c|c|}
\hline \multicolumn{3}{|c|}{ Table 2. Laboratory findings of aTIK patients } \\
\hline Value & Median & Range \\
\hline Glucose $(\mathrm{mg} / \mathrm{dl})$ & 89 & $72-160$ \\
\hline $\mathrm{Na}(\mathrm{mmol} / \mathrm{l})$ & 134 & $131-139$ \\
\hline $\mathrm{K}(\mathrm{mmol} / \mathrm{l})$ & 4.8 & $3.5-7.2$ \\
\hline Creatinine $(\mathrm{mg} / \mathrm{dl})$ & 2.9 & $1.6-6.8$ \\
\hline e GFR $\left(\mathrm{ml} / \mathrm{dk} / 1.73 \mathrm{~m}^{2}\right)$ & 28 & $8-58$ \\
\hline
\end{tabular}

\section{RESULTS}

Among the 32 patients included in the study, the girl/boy ratio was $22 / 10(2.2)$. Mean age was $12 \pm 4.3$ years (9-17). The mean age of the 9 patients with energy drink consumption history was $15 \pm 2.3$ years, with male patient ratio significantly high (boy/girl: $7 / 2)(p<0.05)$. The most common causes in etiology were drugs (18; 56.2\%), energy drinks $(9 ; 28.1 \%)$ and tubulointerstitial nephritis and uveitis syndrome (TINU) (6.2\%) (Table 1). Three patients attended with unexplained acute renal injury and received acute interstitial nephritis diagnosis with biopsy. Among medications, the most common cause was nonsteroidal anti-inflammatory drugs (NSAID) taken for analgesic purposes (66.6\%). This was followed by antibiotics (27.7\%). One patient developed aTIN 2 weeks after beginning a new antiepileptic. The mean duration from onset of symptoms to first attendance at hospital was $3.8 \pm 2.1$ days, with the mean duration between first intake of effective material to onset of symptoms $9 \pm 4.1$ days. Repeated consumption was noted in the group with energy drink intake history especially, this duration increased to 90 days for some patients. The most common attendance symptoms were vomiting in 27 (84.3\%), fatigue (68.7\%), hypertension (56.2\%), abdominal pain (40.6\%), joint pain (34.3\%), fever (31.2\%), skin rash (9.3\%), and eye pain (3.1\%). Mean creatinine at time of attendance was $2.9 \mathrm{mg} / \mathrm{DI}$ (1.6-6.8), while eGFR was $28 \mathrm{~mL} / \mathrm{min} / 1.73 \mathrm{~m}^{2}$ (8-58) (Table 2). One patient with vomiting, reduced urine amount and swelling of the eyes at attendance had history of 1-2 energy drinks per day for the last 3 months did not respond to symptomatic treatment and was taken for emergency hemodialysis. With no underlying comorbid disease, this patient is still monitored for stage 3 chronic kidney disease (CKD). Five patients with no response to symptomatic treatment and refractive proteinuria were administered $1-2 \mathrm{mg} /$ $\mathrm{kg} /$ day dose of steroid treatment for 1 month. In 3 of these patients, creatinine values returned to normal after steroids, while 2 patients developed CKD. Of the 6 patients administered steroid treatment, 5 had aTIN due to energy drinks, while 1 patient had antibiotic use after tonsillitis. In total 3 patients developed CKD. In 2 of the 3 patients the etiology was energy drinks. Of the 2 patients with TINU diagnosis, 1 had high creatinine identified when tested in the eye clinic due to uveitis and was referred to the pediatric nephrology clinic. The other patient had uveitis identified on eye examination performed due to eye pain during attendance. Both patients were girls and renal functions returned to normal with symptomatic treatment while they received local steroid treatment for uveitis. All 18 patients with hypertension at time of diagnosis had proteinuria. Of these patients, 13 began antihypertensive treatment, while 5 patients had hypertension return to normal with symptomatic treatment (Table 3).

\section{Table 3. Features of patients with aTIN linked to} energy drink consumption

\begin{tabular}{|c|c|c|c|c|c|c|c|c|c|}
\hline Patient & 1 & 2 & 3 & 4 & 5 & 6 & 7 & 8 & 9 \\
\hline Gender & M & M & M & M & M & M & M & $\mathrm{F}$ & 1 \\
\hline Age & 13 & 14 & 17 & 16 & 16 & 15 & 15 & 15 & 14 \\
\hline \multicolumn{10}{|c|}{ At the time of attendance } \\
\hline Creatinine(mg/dl) & 4.3 & 6.8 & 2.1 & 1.8 & 3.9 & 4.1 & 2.6 & 3.2 & .6 \\
\hline $\begin{array}{l}\text { GFR }(\mathrm{ml} / \\
\left.\mathrm{dk} / 1.73 \mathrm{~m}^{2}\right)\end{array}$ & 16.3 & 8 & 36 & 39.6 & 17.4 & 17.6 & 26.3 & 20 & 40.7 \\
\hline $\begin{array}{l}\text { Glucose }(\mathrm{mg} / \mathrm{dl}) \\
\mathrm{K}(\mathrm{mmol} / \mathrm{l})\end{array}$ & 115 & 154 & 98 & 102 & 160 & 107 & 98 & 128 & 12 \\
\hline $\mathrm{Na}(\mathrm{mmol} / \mathrm{l})$ & 5.1 & 7.2 & 4.4 & 4.6 & 6.2 & 4.7 & 4.9 & 5.1 & 4.3 \\
\hline Hypertension & 134 & 130 & 138 & 141 & 145 & 134 & 139 & 149 & 136 \\
\hline Proteinuria & + & + & + & - & + & + & - & + & \\
\hline Eosinophilia & + & + & + & - & + & + & - & + & \\
\hline
\end{tabular}

\begin{tabular}{|l|l|l|l|l|l|l|l|l|l|}
\hline $\mathrm{GFR}(\mathrm{ml} /$ & + & - & - & - & + & - & - & + & - \\
$\mathrm{dk} / 1.73 \mathrm{~m}^{2}$ & + & & & & & & & & \\
\hline
\end{tabular}

First intake time to

\begin{tabular}{|l|l|l|l|l|l|l|l|l|l|}
\hline onset of symptoms & 12 & 90 & 6 & 4 & 45 & 30 & 14 & 10 & 7
\end{tabular}

(days)

Need for steroid

Acute dialysis

Last visit CKD

CKD:chronic kidney disease

Detailed sociodemographic and clinical investigation for the total of 9 patients with energy drink intake history is given in Table 3. Contrary to the other aTIN patients, the male sex was dominant in these nine patients (M:F: 7/2) $(\mathrm{P}<0.05)$. Mean age was significantly higher compared to other aTIN patients $(15 \pm 2.3$ years $)(p<0.05)$. A II patients were second- 
ary education-high school students. The duration between energy drink intake and attendance varied from 1 week to 3 months. One patient requiring acute dialysis had continuous consumption history of 1 drink/day for the last 3 months. With no amelioration of clinical-laboratory values with symptomatic treatment, acute hemodialysis began. After dialysis, follow-up for stage 3 CKD continues in the clinic. Patients with energy drink intake duration of $>1$ week had significantly high degrees of glucose elevation, hypertension and proteinuria on attendance $(p<0.05)$. Two patients progressing to CKD had lower eGFR values at attendance compared to others. The reason for drinking energy drinks was to provide energy support during sports (44.4\%), to stay awake during exam periods (33.3\%) and curiosity (22.2\%). Apart from 1 female patient attending with severe vomiting and fatigue 1 week after drinking an energy drink once, all patients had repeated consumption history. The blood glucose levels at attendance were higher in the group with energy drink intake (mean 121 $\mathrm{mg} / \mathrm{dl}$ ). When examined in terms of final examinations, 1 of the 9 patients has stage 3 CKD, and 1 has stage 2 CKD and are monitored under antihypertensive-antiproteinuric treatment. Of the 5 patients administered steroid treatment, 3 have normal GFR but continue on antiproteinuric treatment, while 2 have completed medical treatment and are followed without incident. The 4 patients improving with symptomatic treatment continue clinical follow-up without incident.

\section{DISCUSSION}

In this study we presented outcomes of 32 patients monitored for aTIN diagnosis. Accordingly, patients included in the study were mainly girls, at rates similar to the literature $(1,3,4)$. For patients linked to energy drinks, the male sex was significantly higher (M/F: 7/2). Mean age was $12 \pm 4.3$ years (9-17) in the general patient group, while it was significantly higher in the aTIN cases linked to energy drinks. We can associate this result with the common use of energy drinks among adolescents. When examined in terms of aTIN causes, first place was medications (56.2\%) followed by energy drinks (9\%), different to the literature $(8,9)$. None of our patients with aTIN diagnosis linked to energy drinks had additional medication use or other comorbid disease. The most common symptoms at attendance were vomiting and fatigue similar to the literature $(10,11)$. The number of patients with hypertension was much higher than the literature $(10,11)$. Among the 18 hypertensive patients, 6 had history of energy drink intake. Many studies have shown that energy drinks have side effects in terms of increasing heart rate and especially diastolic blood pressure $(12,13)$. Though this effect is associated with caffeine in the content ( $80 \mathrm{mg}$ in $240 \mathrm{~mL}$ ), these are similar amounts to 1 cup of coffee daily(14). As a result, we cannot hold only caffeine responsible for side effects of these drinks on the kidney. Studies have shown that the basic performance-increasing and alertness-inducing effects of these drinks, with in- creased stimulant effect due to taurine, glucose, ginseng and gingko biloba and B vitamin complexes in the content, come from caffeine (15). Similarly, use due to assisting weight loss linked to the thermogenic effects of caffeine is very common. In this study, of the 9 patients using energy drinks, 4 used it for energy support during sport and to assist weight loss, while 3 stated they used them to stay awake during exam periods. The easy access to these drinks among young people especially increases their exposure to health risks. Though there are many studies about these drinks in Turkey, when the literature is examined there is a very broad increasing side effect spectrum with long-term and recurrent use, especially. The most common of these are palpitations, feeling of being drunk, and increases in diastolic blood pressure and heart rate $(16,17)$. The incidence of these side effects increases especially when taken with alcohol and may cause mortal health problems in the young population with highest levels of curiosity about alcohol (18). Though the 9 patients participating in this study had used these drinks alone without alcohol consumption history, they still were shown to cause permanent health problems. Though rare, a serious encephalopathy tableau linked to taurine is among side effects linked to these drinks (19). Many studies have proven that all these side effects are dose dependent $(16,18,20)$. In our 2 patients developing CKD linked to energy drinks, intake durations were 2 months and 3 months respectively, which proves this data. Similarly, the eGFR values of these two patients were lower at admission compared to other patients. During admission of a female patient developing aTIN after drinking one can of energy drink, eGFR value was higher, the clinic progressed more mildly and she improved without incident. Though the low number of patients prevents generalization of data, we think it is significant in terms of contributing to the literature and providing ideas. There is a need for studies to be performed with higher patient numbers. The number of studies investigating the correlation of energy drinks with aTIN is so low as to be nonexistent. With increasing incidence in recent years and causing permanent kidney damage as seen in our patient outcomes, the need to limit the use of these drinks and to perform studies to increase awareness is obvious.

The glucose levels in our aTIN cases linked to energy drinks were higher on admission compared to other patients (mean $121 \mathrm{mg} / \mathrm{dl}$ ). For patients developing aTIN linked to other causes, this value was significantly lower (mean glucose: 89). Glucose values were higher for patients with intake duration $>1$ month and in the 2 patients developing CKD on admission $(154 \mathrm{mg} / \mathrm{dl}$ and $160 \mathrm{mg} / \mathrm{dl})$. This leads to consideration that the effects of sweeteners included in the ingredients on insulin metabolism should not be ignored $(12,14)$. None of the patients in our group were obese, though it should be remembered that obesity may cause high glucose values (21) 
Similarly, steroid requirements, proteinuria and hypertension were more frequently observed clinical tableau on admission for patients with longer duration of intake. This supports the increase in the incidence of side effects in a dose-dependent manner $(16,17,19)$.

In this study, we presented the general characteristics of our aTIN patients, observed with increasing frequency in the last 1 year. As 9 of our aTIN patients had energy drink intake history, we examined these patients from different aspects and investigated sociodemographic and clinical outcomes. Though performed with a limited number of patients, we think this will be significant to provide an idea for future studies.

\section{CONCLUSION}

In conclusion, the inclusion of energy drink use among candidates for causes of aTIN in recent years is an important health problem. Due to serious side effect profile beginning with acute kidney injury and resulting in CKD, it is a cause that should definitely be questioned in the anamnesis of young patients especially. The increasing use of energy drinks among young people especially and control of accessibility should be the most important duty of the state. Educating young people about this and increasing social awareness in terms of side effects of these drinks carries great importance.

\section{ACKNOWLEDGEMENT}

Peer-Review

Externally Peer Reviewed

Conflict of Interest

The authors declare that they have no conflict of interests regarding content of this article..

Financial Support

The Authors report no financial support regarding content of this article.

\section{Ethical Declaration}

Ethical approval was obtained from Mustafa Kemal University Clinical Research Ethical Committee with date 24/09/2020 and number 02, and Helsinki Declaration rules were followed to conduct this study.

\section{REFERENCES}

1. Roy S, Awogbemi T, Holt RCL. Acute tubulointerstitial nephritis in children- a retrospective case series in a UK tertiary paediatric centre. BMC Nephrol 2020:14;21(1):17. https://doi. org/10.1186/s12882-020-1681-7

2. Raghavan R, Eknoyan G. Acute interstitial nephritis - a reappraisal and update. Clin Nephrol 2014;82(3):149-62. https://doi.org/10.5414/CN10838

3. Taktak A, Uncu N, Acar B, Çaycı \$, Ensari A, Gür G, Köksoy A, Çakar N Acute tubulointerstitial nephritis: a case series and long-term renal outcomes. Turk J Pediatr. 2015;57(6):566-571.
4. Zajjari Y, Montasser D, Sobhi A, Aatif T, Azizi M, Alayoud A, El Kabbaj D. Acute interstitial nephritis in the military hospital of Morocco: Clinical features and renal outcomes. Saudi J Kidney Dis Transpl. 2019;30(6):1407-1414.

5. Ulinski T, Sellier-Leclerc AL, Tudorache E, Bensman A, Aoun B Acute tubulointerstitial nephritis. Pediatr Nephrol. 2012;27(7):1051-7. https://doi.org/10.1007/s00467-011-19159

6. Zhihui Li, Zhijuan Kang, Cuirong Duan, Tianhui Wu, Liang Zhang, Mai Xun, Yunfeng Ding, Yi Zhang, Yan Yin Clinical and pathological features of acute kidney injury in children Ren Fail 2014;36(7):1023-8. https://doi.org/10.3109/088602 2X.2014.917452

7. Greene E, Oman K, Lefler M. Energy drink-induced acute kidney injury. Ann Pharmacother. 2014;48(10):1366-70. doi: 10.1177/106 https://doi.org/10.1177/1060028014541997

8. Oikonomopoulou N, Martínez López AB, J Villaescusa JU, Molina MC, Laiseca, Daniel Nuñez LB, Olalla Álvarez Blanco OA Acute renal damage secondary to acute tubulointerstitial nephritis drug use. Case report Rev Chil Pediatr 2017;88(6):787791. https://doi.org/10.4067/S0370-41062017000600787

9. Krishnan N, Perazella MA Drug-induced acute interstitial nephritis: pathology, pathogenesis, and treatment..Iran J Kidney Dis. 2015;9(1):3-13.

10. Kobayashi $\mathrm{Y}$, Honda M, Yoshikawa N, Ito H. Acute tubulointerstitial nephritis in 21 Japanese children. Clin Nephrol 2000;54(3):191-7.

11. Clavé S, Rousset-Rouvière C, Daniel L, Tsimaratos M Acute tubulointerstitial nephritis in children and chronic kidney disease. Arch Pediatr. 2019;26(5):290-294. https://doi. org/10.1016/j.arcped.2019.05.002

12. Nowak D, Gośliński M, Nowatkowska K. The Effect of Acute Consumption of Energy Drinks on Blood Pressure, Heart Rate and Blood Glucose in the Group of Young Adults. Int J Environ Res Public Health. 2018: 19;15(3):544 https://doi.org/10.3390/ ijerph15030544

13. Ragsdale FR, Gronli TD, Batool N, Haight N, Mehaffey A, McMahon E, Nalli TW, Mannello CM, Sell CJ, McCann PJ , Kastello GM , Hooks T, Wilson T. Effect of Red Bull energy drink on cardiovascular and renal function Amino Acids 2010;38(4):1193-200. https://doi.org/10.1007/s00726-0090330-z

14. Rebholz CM, Young BA, Katz R, Tucker KL, Carithers TC, Norwood AF, Correa A. Patterns of Beverages Consumed and Risk of Incident Kidney Disease. Clin J Am Soc Nephrol. 2019:7;14(1):49-56. https://doi.org/10.2215/CJN.06380518 
15. Paecock A, Martin FH, Carr A. Energy drink ingredients. Contribution of caffeine and taurine to performance outcomes. Appetite. 2013;64:1-4 https://doi.org/10.1016/j. appet.2012.12.021

16. Vercammen KA, Koma JW, Bleich SN. Trends in Energy Drink Consumption Among U.S. Adolescents and Adults, 2003-2016. Am J Prev Med. 2019;56(6):827-833. https://doi.org/10.1016/j. amepre.2018.12.007

17. Brenda M Malinauskas, Victor G Aeby, Reginald F Overton, Tracy Carpenter-Aeby, Kimberly Barber-Heidal A survey of energy drink consumption patterns among college students Nutr J 2007:31;6:35. https://doi.org/10.1186/1475-2891-6-35

18. Kaminer Y. Problematic use of energy drinks by adolescents. Child Adolesc Psychiatr Clin N Am. 2010 ;19(3):643-50 https:// doi.org/10.1016/j.chc.2010.03.015
19. A-X Bigard A-X. Risks of energy drinks in youths Arch Pediatr2010 Nov;17(11):1625-31. https://doi.org/10.1016/j. arcped.2010.08.001

20. Tóth A, Soós R, Szovák E, Najbauer NM, Tényi D, Csábí G, Wilhelm M. Energy Drink Consumption, Depression, and Salutogenic Sense of Coherence Among Adolescents and Young Adults. Int J Environ Res Public Health 2020:17;17(4):1290. https://doi.org/10.3390/ijerph17041290

21. Thombs DL, O'Mara RJ, Tsukamoto M, Rossheim ME et al. Event -level analyses of energy drink consumption and alcohol intoxication in bar patrons. Addict Behav. 2010:35;325-330 https://doi.org/10.1016/j.addbeh.2009.11.004 